\title{
Phytochemical Composition, Larvicidal and Antiproliferative Effect of Canavalia Virosa
}

\author{
S. Suganthi ${ }^{1}$, V. Malarvizhi ${ }^{*}$ \\ ${ }^{1}$ Post Graduate PG and Research Department of Biochemistry, Rabiammal Ahamed Maiden College \\ for Women, Tamilnadu, India \\ ${ }^{2}$ Assistant Professor, PG and Research Department of Biochemistry, Rabiammal Ahamed Maiden \\ College for Women, Tamilnadu, India
}

\begin{abstract}
Medicinal plants possess pharmacological effect due to the presence of bioactive compounds. The target of this presence study is find out the bioactive chemical constituents and to evaluate anti proliferative effect and also analyze the larvicidal effect of methanolic and aqueous extract of dried leaves of canavalia virosa. The preliminary study shows this plant contains the presence of secondary metabolites like alkaloids, flavonoids, saponins, phytosteroids, steroids, tannins, terpenoids and coumarins. This research reports methanolic extract of canavalia virosa shows antiproliferative activity effect against Sk-Mel 2 cells. The larvicidal activity of canavalia virosa was performed against the 4 th instar larvae of anopheles mosquitoes. The larvicidal mortality was observed after 48hours of plant extract exposure. This is an ecofriendly approach for mosquitoes control measure. The results of this present study shows the plant has potential effect against mosquitoes and has antiproliferative effect.
\end{abstract}

Keywords : Larvicidal, Secondary metabolites, Antiproliferative, Anopheles, Canavalia virosa, Sk- Mel 2 cells.

\section{INTRODUCTION}

Almost every civilization has the history of using medicinal plants and been the subject of interest since medieval times. Many different therapeutic plants are used in customary Indian system of the drug for the production of Ayurveda, Siddha and Unani medicine. The curative uses of plants have been welldocumented in ancient Rigveda (1500-400BC) (Hassan et al., 2018).

India has a rich culture of medicinal herbs and species, which includes about more than 2000 species and has a vast geographical area with high potential abilities for ayurvedic, unani, siddha traditional medicines but only very few have been studied chemically and pharmacologically for their potential medicinal value (Gupta et al., 2012)

The antimicrobial properties of plants have been investigated by a number of researchers worldwide, especially in Latin America. In Argentina, a research tested 122 known plants

Species used for therapeutic treatments (Anesini, E.; Perez, C 1993).

Traditionally used medicinal plants produce a variety of compounds of known therapeutic properties. The substances that can either inhibit the growth of pathogens or kill them and have no or least toxicity to 
host cells are considered candidates for developing new antimicrobial drugs. In recent years, antimicrobial properties of medicinal plants are being increasingly reported from different parts of the world .It is expected that plant extracts showing target sites other than those used by antibiotics will be active against drug-resistant microbial pathogens. However, very little information is available on such activity of medicinal plants (Nameirakpam Nirjanta Devil et al., 2014).

India is a fortune place comprising medicinal diversity at all the levels of biodiversity like species, habitat and genetic diversity. Approximately, 4, 80,000 different plants have been discovered worldwide and out of which 28,187plant are medicinal plants. (Pullaiah et al., 2017)

Plants constitute an important source of active natural products which differ widely in terms of structures, biological properties and mechanisms of action various phytochemical components, especially polyphenols such as flavonoids, phenyl propanoids, phenolic acids, tanins etc., are known to be responsible for the free radical scavenging and antioxidant activities of plants. Polyphenols possess many biological effects. These effects are mainly attributed to their antioxidant activities in scavenging free radical, inhibition of per oxidation and chelating transition metals. In generally, polyphenols all share the same chemical patterns, one or more phenolic groups for which they react as hydrogen donors and in that way neutralize free radicals (Bajpai et al ., 2005)

Medicinal plants are a source of great economic value all over the world. Nature has bestowed on us a very rich botanical wealth and a large number of diverse types of plants grow in different parts of the country. Nepal is rich in all the 3 levels of biodiversity, namely species diversity, genetic diversity and habitat diversity. In Nepal thousands of species are known to have medicinal value and the use of different parts of several medicinal plants to cure specific ailments has been in vogue since ancient times. Herbal medicine is still the mainstay of about $75-80 \%$ of the whole population, and the major part of traditional therapy involves the use of plant extract and their active constituents. Following the advent of modern medicine, herbal medicine suffered a setback, but during last two or three decades advances in phytochemistry and in identification of plant compounds effective against certain diseases have renewed the interest in herbal medicines (Govindraju et al., 2009).

The use of plants as medicines predates written human history. Ethno botany "the study of traditional human uses of plants"s is recognized as an effective way to discover future medicines. In 2001, researchers identified 122 compounds used in modern medicine which were derived from "ethno medical" plant sources; $80 \%$ of these have had an ethno medical use identical or related to the current use of the active elements of the plant. Many of the pharmaceuticals currently available to physicians have a long history of use as herbal remedies, including aspirin, digitalis, quinine and opium (Indrayan et al ., 2002).

In India over one and half million medical practitioners use medicinal plants in preventive, promotive and curative applications. In recent years, secondary plant metabolites (phytochemicals) with unknown pharmacological activities have been extensively investigated as a source of medicinal agents (Arora and Kaur, 1999).

Cancer is a major health problem in many parts of the world. It is characterized by loss of control in cellular growth and development leading to excessive proliferation and metastasis. Cancer cell 
growth is different from normal growth. In a normal cell, when DNA is damaged, the cell either repairs the damage or the cell dies. Different types of cancer can behave very differently (Sivapriyadharshini and Padma, 2016).

Skin cancer is a devastating disease, therefore, novel protective and adjuvant treatment methods are needed to improve its prognosis. Medicinal plants and their bioactive compounds have been tested on many skin cancer cell lines and animal models and have shown promising anti-skin cancer results by inhibiting cancer cell development and progression (Penta et al., 2018).

The WHO said the incident of both non-melanoma and melanoma skin cancers has been increasing over the past decades. Currently, between 2 and 3 million non-melanoma skin cancers and 132,000 melanoma skin cancers occur globally each year. One in every three cancers diagnosed is a skin cancer and, according to skin cancer foundation statistics, one in every five Americans will develop skin cancer in their lifetime.

Melanoma is much more common in whites than in other ethnic groups. Overall, the lifetime risk of developing melanoma is about $2.4 \%$ in Caucasians, $0.1 \%$ in Blacks, and $0.5 \%$ in Hispanics (American Cancer Society 2016).

The risk of melanoma increases with age. The average age at the time of diagnosis is about 60. Melanoma is approximately 1.5 times more frequent in males than females. It has been shown that the incidence rate does not significantly differ until the age of 40 , however, after age 75, the incidence becomes almost three times higher in males compared to females (Rastrelli M et al.,2014). In addition, the frequency of its occurrence is closely associated with the constitutive color of the skin and depends on the geographical zone (Leiter U et al., 2008).

Cumulative epidemiologic data from Europe (De Vries E et al., 2014) Canada (Ulmer MJ et al., 1999) and the United States indicate a continuous and dramatic increase in incidence during the last decades(Dennis L et al., 1999)..

Skin cancer is the most common cancer in the United States. It is estimated that approximately 9,500 people in the U.S. are diagnosed with skin cancer, including basal cell carcinoma and squamous cell carcinoma, affects more than 3 million Americans a year (De flora et al., 2005). The technique in controlling mosquitoes depends on the larval stages (egg, larvae, pupae, and adult) on target. Mosquito control includes targeting the adult mosquito through spraying chemical insecticides or by killing the mosquito larvae before they emerge into adulyts via using synthetic larvicides or botanical extracts as an alternative larvicide ( Tiwary et al ., 2007).

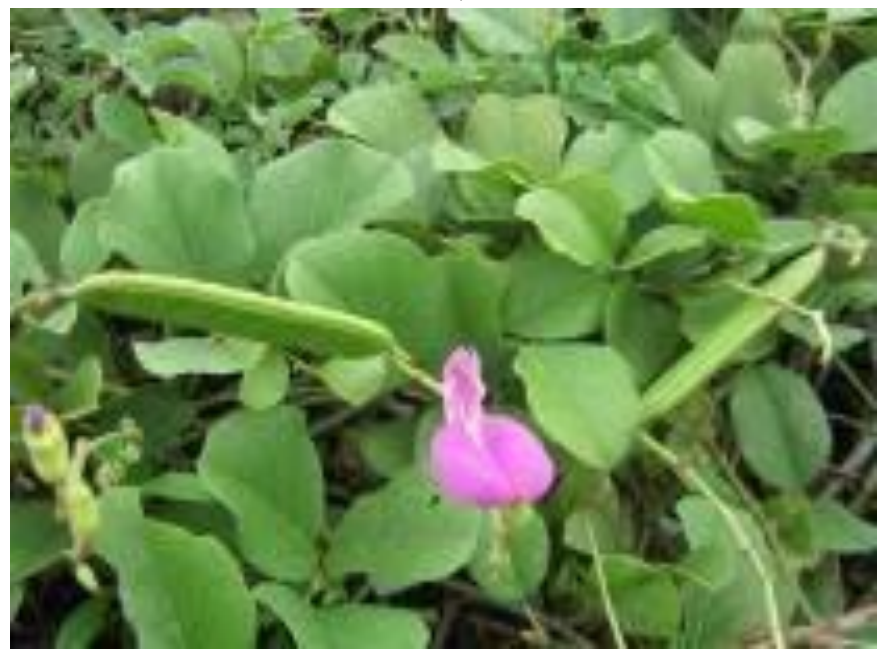

The genus Canavalia is well known owing to the extensive carried out on Canavalia gladiata, Canavalia ensiformis, Canavalia maritime, Canavalia rosea etc. This genus comprises of 51 species and is widely distributed in the tropical and subtropical regions of the world. Among other members of the genus Canavalia ,Canavalia virosa is morphologically very 
similar to Canavalia gladiata and Canavalia ensiformis

(Smartt J. Grain Legumes,1990).

\section{Taxonomic Classification}

\begin{tabular}{|l|l|}
\hline Kingdom & Plantae \\
\hline Sub-kingdom & Tracheobionta \\
\hline Super division & Spermatophyta \\
\hline Division & Magnoliophyta \\
\hline Class & Magnolipsida \\
\hline Sub-class & Rosidae \\
\hline Order & Fabales \\
\hline Family & $\begin{array}{l}\text { Fabaceae/ Leguminosae/ } \\
\text { Papilionaceae }\end{array}$ \\
\hline Genus & Canavalia \\
\hline Species & C. virosa \\
\hline
\end{tabular}

Canavalia virosa extends southward as from Arabia, Socotra and India, through tropical Africa into northeast South Africa. C. virosa is widely distributed all over India, and is commonly found in the Western and Eastern Ghat regions (Westphal E,1974).

\section{MATERIALS AND METHODS}

\section{COLLECTION OF PLANT MATERIALS}

The selected medicinal plant Canavalia virosa was collected from Thiruvarur (Dt), Tamil Nadu, India. The plant leaf was first washed well and dusts were dried at room temperature. These dried materials were macerated to powder form with a mixer grinder and stored in air tight container for further use.

\section{PREPARATION OF THE EXTRACT}

The coarsely powder was packed into soxhlet column and extracted with 70\% methanol for 48 hours (64.5$\left.65.5^{\circ} \mathrm{C}\right)$. The extract was concentrated under reduced pressure at $40^{\circ} \mathrm{C}$ using rotary evaporator and stored in a refrigerator at $2-8^{\circ} \mathrm{C}$ for use in subsequent experiment.

\section{PHYTOCHEMICAL SCREENING}

The canavalia virosa extract was tested for alkaloids, flavonoids, carbohydrates, phenols, glycosides, saponins, phytosteroids, steroids, tannins, terpenoids, coumarins, chlorogenicacid. phytochemical screening of the extract was carried out according to the standard method.

\section{MTT ASSAY}

The cytotoxicity of Canavalia virosa leaves extract on SK-Mel-2 cells was determined by the method of Mosmann, (1983).

\section{PRINCIPLE}

The yellow 3-4, 5dimethylthiozol-2-Yl)2,5diphenyltetrazoliumbromide (MTT) is reduced by mitochondrial dehydrogenase of viable cells yielding a measurable purple formation product. Viable cells contain $\mathrm{NAD}(\mathrm{P}) \mathrm{H}$-dependent reductase, which reduce the MTT reagent to formazon, with a deep purple colour. Formazon crystals are then dissolved using solubilizing solution and absorbance is measured at 500-600 $\mathrm{nm}$ by plate reader.

\section{MTT STOCK SOLUTION}

MTT (50 mg) dye was dissolved in $10 \mathrm{~mL}$ of PBS. After vortexing for $1 \mathrm{~min}$, it was filtered through 0.45 micro filters. The bottle was wrapped with aluminium foil to prevent light, as MTT was light sensitive. The preparation was stored at $4^{\circ} \mathrm{C}$.

\section{PROCEDURE}

Cell viability assay, SK-Mel-2 viable cells were harvested and counted using hemocytometer diluted in DMEM medium to a density of $1 \times 10^{4} \mathrm{cells} / \mathrm{ml}$ was seeded in 96 well plates for each well and incubated 
for $24 \mathrm{~h}$ to allow attachment. After SK-Mel-2 cells treated with control and the containing different concentrations of Canavalia virosa leaves extract 50 to $300 \mu \mathrm{g} / \mathrm{ml}$ were applied to each well. SK-Mel-2 cells were incubated at $37^{\circ} \mathrm{C}$ in a humidified $95 \%$ air and $5 \% \mathrm{CO}_{2}$ incubator for $24 \mathrm{~h}$. After incubation, the drug-containing cells wash with fresh culture medium and the MTT (5 mg/ml in PBS) dye was added to each well, followed by incubated for another $4 \mathrm{~h}$ at $37^{\circ} \mathrm{C}$. The purple precipitated formazan formed was dissolved in $100 \mu \mathrm{l}$ of concentrated DMSO and the cell viability was absorbance and measured 540 $\mathrm{nm}$ using a multi-well plate reader. The results were expressed at the percentage of stable cells with respect to the control. The half maximal inhibitory concentration ( $\left.\mathrm{IC}_{50}\right)$ values were calculated and the optimum doses were analyzed at different time period.

Inhibitory of cell proliferation (\%)

$=\frac{\text { Mean absorbence of the control }- \text { Mean absorbence of the sample }}{X} 10$ Mean absorbence of the control

\section{LARVICIDAL ACTIVITY}

\section{SELECTION, COLLECTION AND CULTURE OF MOSQUITO SPECIES}

Vector species Mosquito was selected for the present study. Mosquito is an epidemiologically important vector involved in the transmission of many viral pathogens including yellow fever, dengue and chikungunya. As a vector species, the growth and multiplication of Mosquito has proven to be very difficult to suppress or control due to their remarkable ability to adapt to various environments, their closeness with humans and their effective reproductive biology. Mosquito larvae was cultured and maintained in the bottle at room temperature with potato extract kept at varying distances around households, were used in the present study. Collected larvae were taken into the laboratory and subjected to species level identification using standard manual .The screened larvae were maintained at $28 \pm$ $2{ }^{\circ} \mathrm{C}$ and subjected for larvicidal activity.

\section{LARVICIDAL BIOASSAY}

Bioassay for the larvicidal activity was carried out using WHO procedure with minor modifications. Twenty larvae, each were introduced into treatment trays containing $50 \mathrm{ml}$ of water. To the treatment set, respective concentrations of the plant extract $(20 \mu \mathrm{l}$, $40 \mu \mathrm{l}, 60 \mu \mathrm{l}, 80 \mu \mathrm{l}$ and 100 $\mu \mathrm{l}$ ) were added from the stock solution; a control was maintained, containing only larvae and $1 \mathrm{ml}$ of methanol. Mortality counts of larvae were monitored at regular intervals i.e. 6, 12, 24, 48, 72 and 96 Hours after Treatment. Larvae were considered dead if they settle and remain motionless in the bottom of the test beaker with no response to light or mechanical stimulus or not recovering life functions even after being transferred to their growth medium.

\begin{tabular}{|l|l|l|l|}
\hline S.NO & Phytochemical & Canavalia virosa \\
\cline { 3 - 4 } & constituents & Aqueous & Methanol \\
\hline 1. & Alkaloids & + & + \\
\hline 2. & Flavonoids & + & - \\
\hline 3. & Carbohydrates & - & - \\
\hline 4. & Phenols & - & - \\
\hline 5. & Glycosides & - & - \\
\hline 6. & Saponins & + & + \\
\hline 7. & Phytosteroids & + & + \\
\hline 8. & Steroids & + & + \\
\hline 9. & Tannins & + & + \\
\hline 10. & Terpenoids & + & + \\
\hline 11. & Coumarins & + & + \\
\hline 12. & Chlorogenic & - & - \\
\hline & acid & & \\
\hline
\end{tabular}

\section{PHYTOCHEMICAL SCREENING}

Phytochemical analysis of the different extracts (Methanol and water) of Canavalia virosa leaves used in this study revealed that the extracts contained the 
presence of Alkaloids, Flavonoids, Coumarins, Terpenoids, Tannins, Steroids, Phytosteroids, Saponins,. These variations are due to number of environmental factors such as climate, altitude, rainfall etc. as mentioned (Kokate et al., 2004).

Anti-proliferative effects of Canavalia virosa on the activity of cytotoxicity in SK-Mel-2 cells

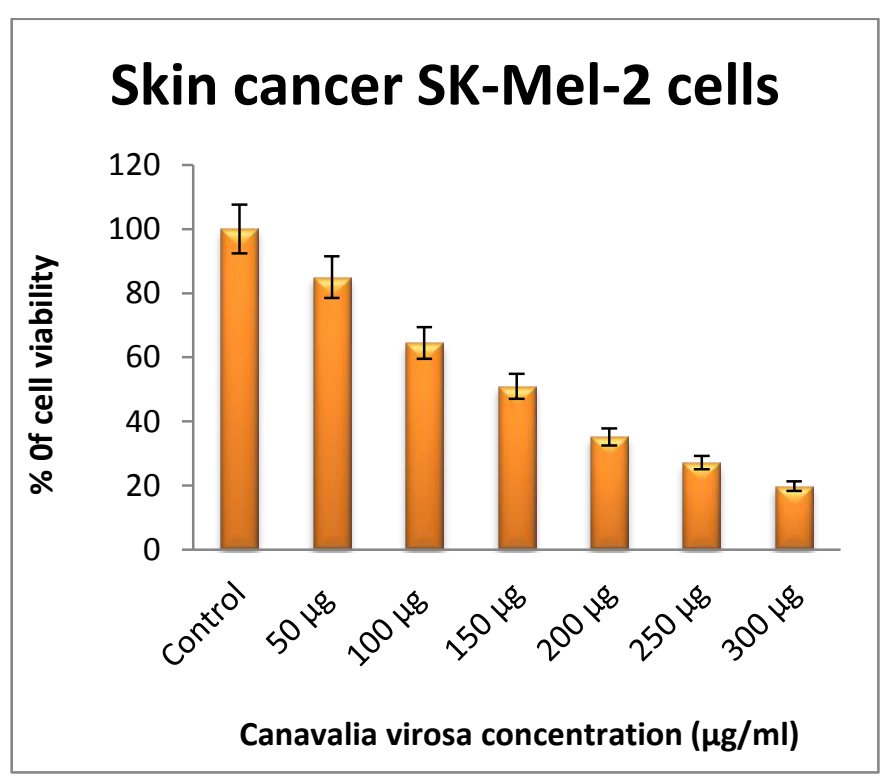

The SK-Mel-2 cells were treated with increasing concentration of Canavalia virosa $(50-300 \mu \mathrm{g} / \mathrm{ml})$ for $24 \mathrm{~h}$ and the results are expressed as a percentage of the control value in presenting as a cell cytotoxicity ratio for SK-Mel-2 cells using MTT assay. Data were presented as mean \pm SD asterisks indicate statically different experiments compared to control.

Morphological changes in control and Canavalia virosa extracts treated SK-Mel-2 cells for $24 \mathrm{~h}$
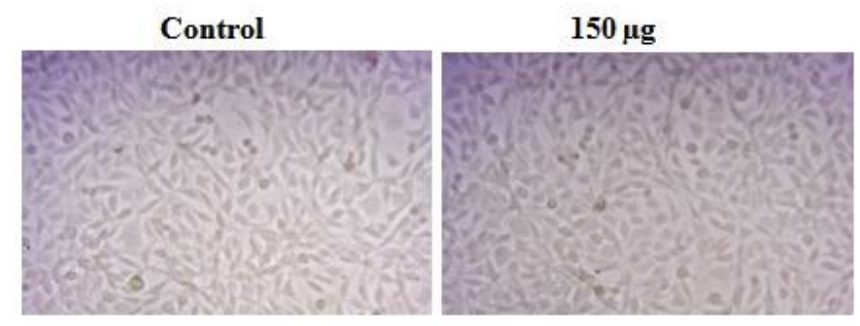

Photomicrograph represents morphological changes in SK-Mel-2 cells such as shrinkage, detachment, membrane blebbing and distorted shape induced by
Canavalia virosa extracts treatment $(150 \mu \mathrm{g} / \mathrm{ml}$ for 24 h) as compared with control. Control showed normal intact cell morphology and their images were captured by light microscope

\begin{tabular}{|l|l|l|l|l|l|l|l|}
\hline \multicolumn{7}{|l|}{ MTT assay } \\
\hline & Control & $50 \mu \mathrm{g}$ & $100 \mu \mathrm{g}$ & $150 \mu \mathrm{g}$ & $200 \mu \mathrm{g}$ & $250 \mu \mathrm{g}$ & $300 \mu \mathrm{g}$ \\
\hline Mean & 109 & 92.65 & 70.31 & 55.48 & 38.28 & 29.6 & 21.64 \\
\hline & 91 & 77.35 & 58.7 & 46.32 & 31.96 & 24.72 & 18.06 \\
\hline & 100.1 & 85.09 & 64.56 & 50.95 & 35.16 & 27.19 & 19.87 \\
\hline Average & 100.0333 & 85.03 & 64.52333 & 50.91667 & 35.13333 & 27.17 & 19.85667 \\
\hline SD & 9.000185 & 7.650176 & 5.805087 & 4.580091 & 3.160084 & 2.440061 & 1.790037 \\
\hline
\end{tabular}

The IC50 values were determined from the Canavalia virosa dose responsive curve where inhibition of $50 \%$ cytotoxicity compared to control cells. All experiments were performed at least three times in triplicate.

The SK-Mel-2 cells were treated with increasing concentration of Canavalia virosa $(50-300 \mu \mathrm{g} / \mathrm{ml})$ for $24 \mathrm{~h}$ and the results are expressed as a percentage of the control value in presenting as a cell cytotoxicity ratio for SK-Mel-2 cells using MTT assay. Data were presented as mean \pm SD asterisks indicate statically different experiments compared to control (Mosmann T 1983).

\section{Statistical analysis}

The values are expressed as mean $\pm \mathrm{SD}$. The statistical comparisons were performed by one way analysis of variance (ANOVA) followed by Duncan's Multiple Range Test (DMRT), using SPSS version 12.0 for windows (SPSS Inc. Chicago; http://www.spss.com). The values are considered statistically significant if the $p$ value was less than 0.05 .

LARVICIDAL BIOASSAY LARVICIDAL EFFECT OF METHANOLIC EXTRACT OF CANAVALIA VIROSA 


\begin{tabular}{|c|c|c|c|}
\hline $\begin{array}{l}\text { S.N } \\
\text { O }\end{array}$ & $\begin{array}{l}\text { CONCENTRATIO } \\
\mathrm{N}(\mathrm{ppm})\end{array}$ & $\begin{array}{l}\text { MORTAL } \\
\text { ITY } \\
\text { RATE } \\
(24 \mathrm{~h}) \\
(100 \%)\end{array}$ & $\begin{array}{l}\text { MORTAL } \\
\text { ITY } \\
\text { RATE } \\
(48 \mathrm{~h}) \\
(100 \%)\end{array}$ \\
\hline 1 & 2000ppm & $20 \%$ & $40 \%$ \\
\hline 2 & 4000ppm & $30 \%$ & $60 \%$ \\
\hline 3 & $6000 \mathrm{ppm}$ & $30 \%$ & $70 \%$ \\
\hline 4 & $8000 \mathrm{ppm}$ & $40 \%$ & $90 \%$ \\
\hline 5 & 10000ppm & $60 \%$ & $100 \%$ \\
\hline
\end{tabular}

\begin{tabular}{|l|l|l|l|}
\hline 1 & $2000 \mathrm{ppm}$ & $10 \%$ & $20 \%$ \\
\hline 2 & $4000 \mathrm{ppm}$ & $20 \%$ & $20 \%$ \\
\hline 3 & $6000 \mathrm{ppm}$ & $30 \%$ & $30 \%$ \\
\hline 4 & $8000 \mathrm{ppm}$ & $50 \%$ & $50 \%$ \\
\hline 5 & $\begin{array}{l}10000 \mathrm{pp} \\
\mathrm{m}\end{array}$ & $50 \%$ & $70 \%$ \\
\hline
\end{tabular}

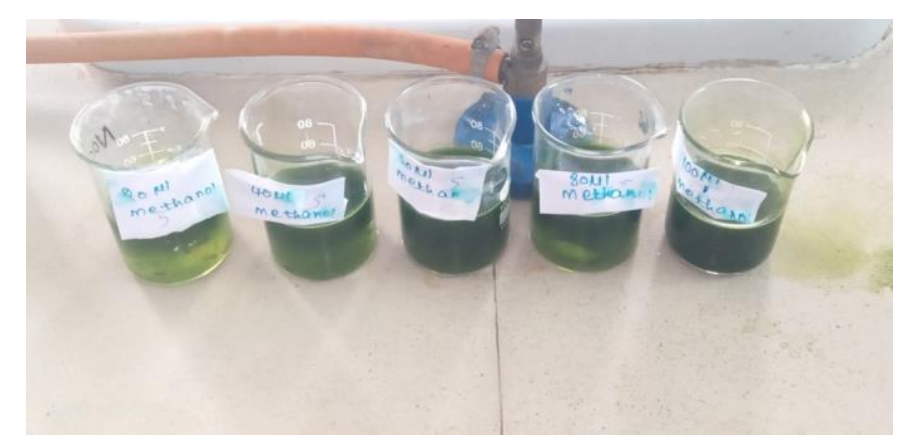

shows the larvicidal activity of methanolic extract of Canavalia virosa

LARVICIDAL BIOASSAY LARVICIDAL EFFECT OF AQUEOUS EXTRACT OF CANAVALIA VIROSA

\begin{tabular}{|l|l|l|l|}
\hline Sr & CONCE & MORTA & MORTAL \\
No & $\begin{array}{l}\text { NTRATI } \\
\text { ON } \\
\text { S.NO } \\
(\mathrm{ppm})\end{array}$ & LITY & ITY \\
\cline { 2 - 4 } & & $\begin{array}{l}\text { RATE } \\
(24 \mathrm{~h})\end{array}$ & $\begin{array}{l}\text { RATE } \\
(48 \mathrm{~h})\end{array}$ \\
\hline
\end{tabular}

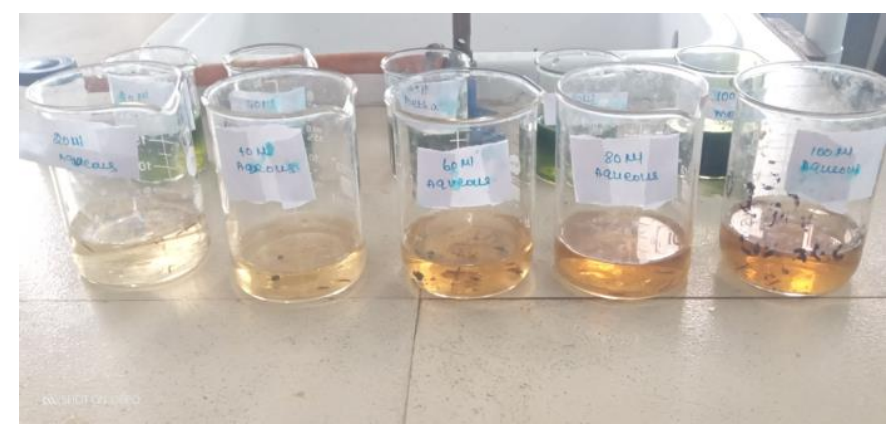

shows the larvicidal activity of aqueous extract of Canavalia virosa.

In the current investigation, larvicidal activity of Canavalia virosa formulation methanolic extract was carried out against mosquito larvae. Mortality was observed for 24 and 48 hours. The results of the present study revealed that, methanolic extracts of Canavalia virosa formulation possessed high larvicidal activity. The extracts showed moderate larvicidals effects after $24 \mathrm{~h}$ of exposure at 2000ppm. However, the highest larval mortality was found at 10000ppm after $48 \mathrm{~h}$.

The plant extract against fourth instar larvae of Ae.aegpti, An.stephensi and cx.quinquefasciatus after $24 \mathrm{~h}$ exposure. The results clearly indicate that the plant extract of L.camaraaculeate at very low concentrations was toxic against all the three mosquito species tested. The methanolic plant extract was found to be more potent against 
Cx.quinquefasciatus and An.stephensi with LC50 and LC90 value of $35.36 \mathrm{ppm}$ and $107.42 \mathrm{ppm}$ and $35.65 \mathrm{ppm}$ and $106.95 \mathrm{ppm}$ when compared to Ae.aegypti with LC50 and LC90 of $39.54 \mathrm{ppm}$ and $118.62 \mathrm{ppm}$ respectively. Methanolic extract of L.camara aculeata showed $100 \%$ mortality at $150 \mathrm{ppm}$ against the fourth instar larvae of An.stephensi, Ae.aegypti and Cx.quinquefasciatus. Ethanolic whole plant extracts were found to be equally effective against the fourth instar larvae of all the three mosquito species. LC50 and LC90 values were $50.17 \mathrm{ppm}$ and $155.64 \mathrm{ppm}$ against $\mathrm{Cx}$.quinquefasciatus when compared to Ae.aegypti (60.93ppm and 181.99ppm) and An.stephensi (79.03ppm and 237.19ppm) respectively. All other tested extracts also showed mosquito larvicidal activity at a relatively high concentration when compared to methanol and ethanol plant extracts (Periaswamy Hemalatha et al.,2015). In the present study the methanolic extract of leaves of canavalia virosa showed the higher larvicidal activity than aqueous extract.

\section{III.CONCLUSION}

Methanol and aqueous extract of canavalia virosa was prepared based on standard protocols and they were assayed for following test.

Preliminary phytochemical analysis of aqueous extract and methanol extract of canavalia virosa showed positive results for Alkaloids, Flavonoids, Coumarins, Terpenoids, Tannins, Steroids, Phytosteroids, Saponins.

For larvicidal bioassay, WHO standard procedure was allowed with slight modifications and observed after 24 hours and 48 hours. At the end of 24 hours according to extract concentration the mortality rate, at $2000 \mathrm{ppm}, 4000 \mathrm{ppm}, 6000 \mathrm{ppm}$ concentration only $30 \%$ of mortality was observed. In $8000 \mathrm{ppm}$ concentration $40 \%$ of mortality rate was observed. In
$10000 \mathrm{ppm}$ concentration $60 \%$ of mortality was observed, whereas after 48hours all the larvae were died irrespective of concentrations. Based on the present study, the methanol extract of canavalia virosa could be used as a best larvicidal drug candidate.

The MTT assay also suggests the presence of antipro liferative effect of canavalia virosa.

\section{ACKNOWLEDGEMENT}

The authors are grateful thanks to the secretary, trust members and principal of Rabiammal ahamed maiden college for women, Thiruvarur - 610001, Tamilnadu, India for providing necessary laboratory facilities to complete this manuscript.

\section{REFERENCES}

[1]. American Cancer Society. [Accessed June 3, 2016].

http://www.cancer.org/cancer/skincancermelanoma/detailedguide/melanoma-skincancer-key-statistics

[2]. Anesini, E.; Perez, C. Screening of plants used in Argentine folk medicine for antimicrobial activity. J. Ethnopharmacol. 39, 119-128, 1993.

[3]. Arora DS; Kaur J, Antimicrobial activity of spices, Int J. Antimicrob Agents.1999 ;12(3):257-62.

[4]. Bajpai M., pande A., tewari S.K., and prakash D., (2005). Phenolic contents and antioxidant activity of some food and medicinal plants. International journal of food sciences and nutrition, 56, 287-291.

[5]. De Flora.S, L.R. Ferguson overview of mechanisms of cancer chemopreventive agents mutat. Res., 591 (1) (2005) pp.815. 
[6]. De Vries E, Coebergh JW. Cutaneous malignant melanoma in Europe. Eur J Cancer. 2004;40:2355-2366.

[7]. Govindraju K, Kiruthiga V, Ganesh Kumar V and Singaravelu G. Extracellular synthesis of silver nanoparticles by a marine alga, Sargassum wightii Grevilli and their antibacterial effects. Journal of Nanoscience and Nanotechnology . 2009; 9: 5497-5501.

[8]. Gupta AK, Sharma M, Tandon N, Boerhaavia diffusa Linn. (Nyctaginaceae). In: Gupta AK, Tendon N, editors, Reviews on Indian Medicinal Plants, V 4. S. Narayan and Co, New Delhi, India, 2004.

[9]. Hassan, A., S. Hassan and M.A. Nasir (2018). An Ethnobotanical Study of Medicinal Plants used by Local People of Neel Valley, Ramban, Jammu and Kashmir, India. S.S.R.G. Int. J.Agric. Env. Sci., 5:17-20.

[10]. Indrayan AK, Sharma A, Gideria BS and Gupta CP. Antimicrobial activity of dye from Caesalpina sappan (Patang/Braziluvoral). Indian J. Microbiol.2002; 42: 359-360.

[11]. Kokate, C.K., Purohit, A.P., and Gokhale,S.B. 2004. Practical Pharmacognosy, 2nd edition.

[12]. Lasithiotakis K, Leiter U, Gorkievicz R, et al. The incidence and mortality of cutaneous melanoma in Southern Germany: trends by anatomic site and pathologic characteristics, 1976 to 2003. Cancer. 2006;107:1331-1339.

[13]. Leiter U, Garbe C. Epidemiology of melanoma and nonmelanoma skin cancer-the role of sunlight. Adv Exp Med Biol. 2008;624:89-103.

[14]. Mansson-Brahme E, Johansson H, Larsson O, Rutqvist L, Ringborg U. Trends in incidence of cutaneous malignant melanoma in a Swedish population 1976-1994. Acta Oncol. 2002;41:138-146.

[15]. Mosmann T. Rapid colorimetric assay for cellular growth and survival: application to proliferation and cytotoxicity assays. J Immunol Methods. 1983;65:55-63.

[16]. Nameirakpam ND, Dheeban SP and Sutha S. Biomimetic Synthesis nanoparticle-hydrogel composites. Journal of Advanced Materials. 2014; 16: 1074-1079.

[17]. Penta.D, B.S.Somashekar, S.M.Meeran Epigenetics of skin cancer: interventions by selected bioactive phytochemicals photodermatol. Photoimmunol. Photomed., 3(1) (2018), pp. $42-49$

[18]. Periyaswamy hemalatha, Devan elumalai, Arumugam Janaki, Muthu babu, Kuppan velu, Kanayairam velayutham and Patheri kunyil kaleena., (2015), Larvicidal activity of Lantana camara aculeate against three important mosquito species, Journal of entomology and zoology studies, 3(1): 174-181.

[19]. Pullaiah., T., B. Bahadur and K.V. Krishnamurthy (2015). Plant Biology and Biotechnology: Volume 1: Plant diversity organization, function and improvement. Springer India, 177-195.

[20]. Rastrelli M, Tropea S, Rossi C, Alaibac M. Melanoma: epidemiology, risk factors, pathogenesis, diagnosis and classification. In Vivo. 2014;28:1005-1011.

[21]. Sivapriyadharshini S, Padma PR. Kaempferol exerts a differential effect on KB oral Carcinoma cells and normal human buccal cells. Int $\mathrm{j}$ pharm bio sci. 2016; 7(3): $1244-1252$.

[22]. Smartt J. Grain Legumes. Cambridge University Press,Cambridge, UK. Second Edition 1990: 301-309.

[23]. Stang A, Pukkala E, Sankila R, Söderman B, Hakulinen T. Time trend analysis of the skin melanoma incidence of Finland from 1953 through 2003 including 16,414 cases. Int J Cancer. 2006;119:380-384.

[24]. Tiwary M., Naik S N., Tewary D K., Mittal P K., and Yadav S., (2007), chemical composition and 
larvicidal activities of the essential oil of Zanthoxylumarmatum DC (Rutaceae) against three mosquito vectors, Journal of vector borne diseases, 44(1): 198-204. Vallabh Prakashan, New Delhi, 466-470.

[25]. Ulmer MJ, Tonita JM, Hull PR. Trends in invasive cutaneous melanoma in Saskatchewan 1970-1999. J Cutan Med Surg. 2003;7:433-442.

[26]. Westphal E. Pulses in Ethopia, their Taxonomy and Agricultural significance. Belmontia 1974; 3(9): pp. 1-363.

\section{Cite this article as :}

S. Suganthi, V. Malarvizhi, "Phytochemical Composition, Larvicidal and Antiproliferative Effect of Canavalia Virosa", International Journal of Scientific Research in Science and Technology (IJSRST), Online ISSN : 2395-602X, Print ISSN : 23956011, Volume 7 Issue 3, pp. 197-206, May-June 2020. Available at doi : https://doi.org/10.32628/IJSRST207333 Journal URL : http://ijsrst.com/IJSRST207333 